\title{
PRZEMÓWIENIE REKTORA KUL Ks. Prof. dra hab. Stanisława Wilka na otwarcie sympozjum ,Jan Paweł II a antyk chrześcijański”
}

\section{Szanowni Państwo!}

Chrześcijaństwo to siła i źródło kulturotwórcze. Wytworzyło własną kulturę oraz przekazało czasom współczesnym kulturę antyczną, upowszechniając i wzbogacając ją o nowe treści. Powrót do źródeł chrześcijaństwa - do antyku - to według Ojca Świętego Jana Pawła II odrodzenie zdrowej myśli teologicznej, które jest potrzebą obecnych czasów i priorytetowym zadaniem teologii.

Serdecznie i gorąco witam wszystkich obecnych tu prelegentów i uczestników, rozpoczynającego się sympozjum patrystycznego na temat: Jan Paweł II $a$ antyk chrześcijański, które zorganizował Instytut Badań nad Antykiem Chrześcijańskim. Bardzo trafnie i bezpośrednio wpisuje się ono we wszystkie sesje i konferencje naukowe bieżącego roku akademickiego, który w szczególny sposób poświęcamy upamiętnieniu 20. rocznicy wizyty Ojca Świętego w diecezji lubelskiej i w naszym Uniwersytecie. Organizatorzy sympozjum zaprosili nas do refleksji nad przesłaniem Ojca Świętego Jana Pawła II odnoszącym się do czasów starożytnych. Jan Paweł II bowiem w swoim nauczaniu - jak chyba żaden z jego poprzedników - często nawiązywał do ważnych wydarzeń w Kościele starożytnym, bądź rocznic związanych z życiem, nauczaniem i działalnością Ojców Kościoła. Śledząc to nauczanie warto wymienić chociażby 9 Listów Apostolskich, poświęconych m.in. św. Bazylemu (Patres Ecclesiae, 1980), św. Benedyktowi (Sanctorum altrix, 1980), św. Augustynowi (Augustinum Hipponensem, 1986), św. Grzegorzowi Wielkiemu (Plurimum significans, 1990), św. Ambrożemu (Operosam diem, 1997), czy wydarzeniom historycznym starożytnego Kościoła, jak 1200. rocznicy Soboru Nicejskiego II (Duodecimum saeculum, 1987) lub 1600. rocznicy I Soboru Konstantynopolitańskiego i 1550. rocznicy Soboru Efeskiego (A Concilio Constantinopolitano, 1981). Należy do nich dodać bardzo liczne przemówienia i pisma, kierowane przezeń do osób i instytucji, zajmujących się szeroko pojętymi studiami patrystycznymi. W naszej refleksji nie można też pominąć wcześniejszego zaangażowania kard. Karola Wojtyły na rzecz rozwoju studiów patrystycznych w Polsce. To z jego inspiracji w 1977 r. powstała Sekcja Patrystyczna przy Komisji Epis- 
kopatu Polski ds. Nauki Katolickiej; on także popierał powstanie Zakładu Badań nad Antykiem Chrześcijańskim KUL (1969), potem wspierał finansowo jego działalność, a w 1989 r. z okazji 30-lecia jego działalności i periodyku „Vox Patrum” przesłał nawet telegram gratulacyjny.

W historii Kościoła czasy starożytne są szczególnym bogactwem, okresem niezwykle intensywnego kształtowania się szeroko rozumianej kultury, rozwijania doktryny i budowania tożsamości Kościoła. Jest to skarbiec, z zasobów którego także dzisiaj możemy czerpać wiele cennych treści i duchowych wzorów. Przywoływanie przez Jana Pawła II osób i wydarzeń z życia Kościoła starożytnego było podyktowane przekonaniem, że tylko człowiek, który zna korzenie swej religii i kultury może ją przyjąć, według niej kształtować swoje życie i wpływać na formację społeczeństw. Czy dzisiaj na początku XXI wieku my chrześcijanie nie powinniśmy częściej zastanawiać się chociażby nad tymi słowami św. Ignacego Antiocheńskiego: „Dla mnie proście tylko o moc ducha i ciała, bym nie tylko mówił, ale i chciał, abym nie tylko uchodził za chrześcijanina, ale był nim rzeczywiście. Jeśli zostanę nim rzeczywiście, będę miał prawo nosić to imię" (List do Rzymian 3,1).

Nauczanie każdego Papieża jest dla teologów i dla wszystkich katolików niezwykle ważne i zobowiązujące. Środowisko naukowe naszego Uniwersytetu, który przyjął do swej oficjalnej nazwy, jako jedyny w świecie uniwersytet, imię Jana Pawła II, czuje się w sposób szczególny powołane do tego, aby nauczanie swego Patrona, Wielkiego Papieża-Polaka rozważać, komentować i tą refleksją dzielić się z całą wspólnotą Kościoła.

Organizatorom rozpoczynającego się sympozjum Jan Paweł II a antyk chrześcijański serdecznie dziękuję za trud jego zorganizowania. Wszystkim zaś prelegentom i uczestnikom z całego serca życzę, aby zgłębianie treści związanych z życiem i nauczaniem Ojców Kościoła, któremu patronuje Jan Paweł II, było twórcze i owocne. Niech to spotkanie przenika moc Ducha Świętego, Który stale przybliża do Prawdy niezmiennie obecnej w Kościele Chrystusowym.

Szczęść Boże! 